\title{
ARTIKELEN
}

\section{Verborgen strijd in het veiligheidsdomein: over samenwerking tussen politie en gemeente bij de bestuurlijke aanpak van overlast en criminaliteit}

\author{
Renze Salet
}

Bij de lokale aanpak van overlast en criminaliteit hebben Nederlandse burgemeesters uiteenlopende bevoegdheden voorhanden. Dit artikel gaat in op de wijze waarop gemeenten en politie samenwerken bij de toepassing van gebiedsverboden, woningsluitingen en Bibob-toetsen. Daarbij wordt nagegaan in hoeverre deze samenwerking zich vanuit het kader van interorganisationele samenwerking laat begrijpen. Geconstateerd wordt dat in een deel van de gevallen de afstand tussen gemeenten en politie groot is. Deze afstand heeft nadelige gevolgen voor de samenwerking. Geconcludeerd wordt dat de positie die politie en gemeenten innemen in het veiligheidsdomein ambivalent is en dat sprake lijkt te zijn van een verborgen strijd.

\section{$1 \quad$ Inleiding}

Tot midden jaren tachtig werd de aanpak van overlast en criminaliteit in Nederland als exclusieve taak van politie en Openbaar Ministerie beschouwd. De afgelopen decennia is daarin verandering gekomen. Onder andere het ontstaan van een 'high crime society', verlies van een vanzelfsprekend gezag van de overheid (waaronder politie en justitie) en ervaren machteloosheid in de aanpak van problemen, hebben bijgedragen aan het ontstaan van een nieuwe verantwoordelijkheidsverdeling in de veiligheidszorg (Boutellier, 2005; Terpstra, 2010). Nederlandse gemeenten hebben in de aanpak van lokale overlast en criminaliteit (zowel kleine criminaliteit als georganiseerde criminaliteit) een steeds belangrijker positie gekregen. Deze groei in verantwoordelijkheid voor gemeenten ging gepaard met een toename van het aantal door burgemeesters in te zetten bevoegdheden (Sackers, 2010; De Jong, 2013; Prins, 2016), zoals voor het aanwijzen van een veiligheidsrisicogebied waar preventief kan worden gefouilleerd, het opleggen van gebiedsverboden en huisverboden, het sluiten van panden of de mogelijkheid vergunningen te weigeren of in te trekken ter preventie van criminaliteit.

Verwacht kan worden dat burgemeesters voor de toepassing van deze bevoegdheden in grote mate afhankelijk zijn van de politie. Zo spelen de politie en haar informatie vermoedelijk een grote rol bij de besluitvorming. Ook ligt het voor de hand dat de politie bij de uitvoering, controle en handhaving hiervan betrokken is. De zorg voor de (lokale) handhaving van de openbare orde en de rechtshandha- 
ving zijn immers primair in handen van de politie. Daar komt bij dat de burgemeester zich volgens de Gemeentewet bij de inzet van zijn bevoegdheden ter handhaving van de openbare orde kan bedienen van de onder zijn gezag staande politie.

Het voorgaande roept uiteenlopende vragen op over samenwerking tussen politie en gemeente bij de inzet van lokale bestuurlijke bevoegdheden. Hiernaar is nog weinig empirisch onderzoek gedaan. In deze bijdrage wordt nagegaan op welke wijze de samenwerking tussen deze organisaties in de praktijk verloopt, welke factoren en omstandigheden daarbij een rol spelen en welke gevolgen deze samenwerking heeft voor de verhouding tussen gemeente en politie in het veiligheidsdomein. Op basis van een recent onderzoek naar de samenwerking tussen politie en gemeente zal geconcludeerd worden dat de posities van de politie en gemeenten in het veiligheidsdomein tamelijk ambivalent zijn en sprake lijkt te zijn van een verborgen strijd in het veiligheidsdomein.

De bestuurlijke bevoegdheden die de burgemeester voorhanden heeft om lokale overlast en criminaliteit aan te pakken lopen uiteen, onder andere naar hun aard en de problematiek waarvoor ze kunnen worden ingezet. De bevoegdheden verschillen ook naar de mate waarin en de wijze waarop de politie daarbij betrokken is. Dit artikel concentreert zich op de samenwerking bij drie bevoegdheden, namelijk gebiedsverboden, woningsluitingen en Bibob-toetsen. Vermoed kan echter worden dat de bevindingen ook relevant zijn voor de samenwerking bij andere bevoegdheden.

$\mathrm{Bij}$ de toepassing van burgemeestersbevoegdheden kunnen uiteenlopende partijen betrokken zijn. Ook kunnen de bevoegdheden onderdeel uitmaken van een bredere aanpak of worden toegepast in een breder samenwerkingsverband. Hier ligt echter de nadruk op de samenwerking tussen politie en gemeenten. Hoewel het hier formeel gaat om burgemeestersbevoegdheden spelen het gemeentelijk apparaat en gemeenteambtenaren hierbij een belangrijke rol. Politiemensen (en vertegenwoordigers van andere partijen) krijgen vooral daarmee te maken.

Dit artikel is gebaseerd op een recent empirisch onderzoek naar de vraag op welke wijze lokale bestuurlijke bevoegdheden worden gebruikt voor de aanpak van criminaliteit en overlast. Daarbij kwam tevens aan de orde welke gevolgen toepassing van deze bevoegdheden en de betrokkenheid van de politie daarbij hebben voor het politiewerk (Salet \& Sackers, 2019a). In het verlengde van dit onderzoek wordt hier een wat andere vraag aan de orde gesteld, namelijk hoe de samenwerking tussen politie en gemeente in de praktijk plaatsvindt, welke factoren en omstandigheden daarbij een rol spelen en welke gevolgen deze samenwerking heeft voor de positie van politie en gemeenten in het veiligheidsdomein. Dit wordt hier benaderd vanuit het perspectief van interorganisationele samenwerking. Deze bijdrage vangt daarom aan met enkele theoretische noties die van belang zijn om te kunnen begrijpen hoe de samenwerking tussen organisaties in de praktijk verloopt (par. 2). Vervolgens wordt kort ingegaan op de methoden van onderzoek (par. 3) en wordt op hoofdlijnen de toepassing van de drie bevoegdheden in de praktijk beschreven (par. 4). Daarna komen de samenwerking tussen politie en gemeenten aan de hand van de drie geselecteerde bevoegdheden (par. 
5) en de bevorderende en belemmerende factoren die daarbij van belang zijn (par.

6) aan de orde. Vervolgens komen de afstand tussen politie en gemeenten (par. 7) en de positie van deze partijen in het veiligheidsdomein (par. 8) aan de orde. Dit artikel concludeert dat sprake is van een verborgen strijd die politie en gemeenten voeren in het veiligheidsdomein (par. 9).

\section{Interorganisationele samenwerking in de veiligheidszorg}

De veranderde verantwoordelijkheidsverdeling bij de aanpak van maatschappelijke onveiligheid sinds begin jaren negentig heeft er onder meer toe geleid dat daarbij steeds meer verschillende partijen, zowel publieke als private, zijn betrokken (o.a. Boutellier, 2005; Terpstra, 2010; Schuilenburg, 2012). Deze verandering heeft zich niet alleen in Nederland voorgedaan, maar ook in veel andere landen (o.a. Dupont, 2004; Terpstra, 2008). Onder de noemer van 'lokaal integraal veiligheidsbeleid' wordt van verschillende partijen verwacht dat zij hun verantwoordelijkheid nemen in de preventie en aanpak van onveiligheid (Van Steden, 2011; Cachet \& Prins, 2012). Het besef dat interorganisationele samenwerking noodzakelijk is voor de bestrijding van overlast en criminaliteit, is de afgelopen 25 jaar gegroeid (Terpstra \& Kouwenhoven, 2004; Bryson, Crosby \& Middleton Stone, 2006; Weber \& Khademian, 2008; Prins \& Cachet, 2011; Page e.a., 2015). Afzonderlijke organisaties zouden immers onvoldoende 'kennis, capaciteit of mandaat' hebben om problemen van overlast en criminaliteit aan te pakken (Waardenburg e.a., 2016). Deze ontwikkeling heeft geresulteerd in de totstandkoming van diverse lokale samenwerkingsverbanden (o.a. Terpstra \& Kouwenhoven, 2004).

Op basis van eerder onderzoek naar interorganisationele samenwerking in de Nederlandse veiligheidszorg zijn vier ideaaltypen onderscheiden (Terpstra \& Kouwenhoven, 2004), waarbij de mate van afstemming en integratie van de werkzaamheden uiteenloopt. ${ }^{1}$ Het eerste model is het 'communicatiemodel' (vgl. het information exchange network (Whelan \& Dupont, 2017: 681). Dit type samenwerking is beperkt tot onderlinge communicatie en informatie-uitwisseling. Wanneer bij de samenwerking rondom een bepaald probleem sprake is van een gezamenlijk probleembesef wordt gesproken van een 'coöperatiemodel' (vgl. het problem-solving network (Whelan \& Dupont, 2017: 681). Betrokken partijen behouden echter hun eigen grenzen en identiteit. Bij het zogeheten coördinatiemodel werken partijen op systematische wijze samen, is sprake van gezamenlijk probleembesef, informatie-uitwisseling en afstemming van de werkzaamheden (vgl. het coordination network (Whelan \& Dupont, 2017: 681). Vaak worden bij dit type samenwerking de middelen gebundeld. Het 'federatiemodel' gaat nog een stap verder. Bij dit

1 Deze modellen zijn ontleend aan Johnston \& Shearing, 2003. Johnston en Shearing onderscheiden nog een vijfde model, het fusiemodel, waarbij betrokken partijen zo nauw samenwerken dat zij nauwelijks van elkaar te onderscheiden zijn bij hun werk aan een gezamenlijk gedefinieerd probleem (Terpstra \& Kouwenhoven, 2004). Dit model werd in de Nederlandse situatie echter niet aangetroffen ten tijde van het onderzoek van Terpstra en Kouwenhoven en is ook in onderhavige studie niet aan de orde. 
type samenwerking is hier bovenop nog sprake van centrale sturing (Terpstra \& Kouwenhoven, 2004: 147-155).

Het verloop van interorganisationele samenwerking bij de aanpak van overlast en criminaliteit en de mate waarin een gemeenschappelijke werkwijze ontstaat, is afhankelijk van uiteenlopende interne en externe factoren (Terpstra, 2001; Bakker, 2009; O’Toole, 2012; Popp e.a., 2014). Volgens Benson (1975) is de mate van integratie van de werkzaamheden bij interorganisationele samenwerking onder meer afhankelijk van de vraag of op het niveau van 'superstructure' (bovenbouw) consensus heerst over de passende rol, het werkterrein, de aard van de taken en de werkwijzen van de betrokken partijen. Daarnaast is van belang dat partijen positief oordelen over het belang van elkaars werk en moet sprake zijn van coördinatie en afstemming van de werkzaamheden. In hoeverre hiervan sprake is bij samenwerking en bij de wijze waarop betrokken partijen zich opstellen, wordt volgens Benson (1975: 231-236) beïnvloed door de mate waarin zij op het niveau van substructure (basis) in staat zijn hulpbronnen te verdelen, verwerven en beschermen. Dit idee van Benson is verder uitgewerkt in de notie dat wederzijdse afhankelijkheid of interdependentie van belang is bij de mate waarin sprake is van een gemeenschappelijke, geïntegreerde werkwijze (o.a. Van der Zwaan, 1990: 415-416). In dit verband worden (onder andere) symbiotische interdependentie en competitieve interdependentie onderscheiden. Van het eerste is sprake als betrokken partijen elkaar aanvullen en aan elkaars taken en doelen kunnen bijdragen. Van competitieve interdependentie is sprake als partijen concurreren met elkaar doordat zij gelijksoortige organisaties betreffen en overlap bestaat in domein, hulpbronnen of producten (Terpstra, 2001: 146).

Naast de hiervoor beschreven factoren die de samenwerking beïnvloeden, zijn op basis van empirisch onderzoek naar interorganisationele samenwerking in de veiligheidszorg op het niveau van de uitvoering nog andere factoren te onderscheiden. Allereerst is samenwerking gebaat bij informele en open relaties tussen de betrokken partijen, waarbij sprake is van een zekere mate van stabiliteit en continuïteit. Partijen moeten elkaar daarbij vertrouwen (Terpstra \& Kouwenhoven, 2004; Bakker, 2009; Schuilenburg \& Van der Wagen, 2011). Onder meer een hoge contactfrequentie, wederzijds respect, begrip en vertrouwen bevorderen de samenwerking (Van den Berg \& Maas, 2013). Een hoge mate van samenwerking ontstaat ook wanneer partijen regelmatig informatie met elkaar uitwisselen en zich flexibel opstellen. Ook probleemgerichtheid komt de samenwerking ten goede (Terpstra \& Kouwenhoven, 2004; Bakker, 2009). Daarbij is ook van belang dat sprake is van een heldere probleemdefinitie waarop de samenwerking zich richt en dat consensus bestaat over de aanpak (Waardenburg e.a., 2016; Lam, Van der Wal en Kop, 2018). Betrokken partijen hebben daarnaast voldoende steun en autonomie in hun eigen organisatie nodig (Terpstra \& Kouwenhoven, 2004; Bakker, 2009). Interne communicatie is hierbij van belang. Bovendien moet het doel van de samenwerking duidelijk zijn en het belang van samenwerking door organisaties worden gezien (Van Gestel \& Verhoeven, 2011: 28). Overigens lijkt het niet altijd noodzakelijk dat organisaties het centrale doel van de samenwerking onderschrijven (Van den Berg \& Maas, 2013: 227). Ten slotte hangt succesvolle samenwerking ook af van de wijze waarop de coördinatie plaatsvindt (o.a. Tops, Van Os 
en Van der Torre, 2017; Van der Steen e.a., 2016) en de mate waarin partijen elkaars inzet en betrokkenheid positief beoordelen (Terpstra \& Kouwenhoven, 2004; Bakker, 2009). In het volgende wordt onder andere nagegaan in hoeverre de samenwerking tussen politie en gemeenten zich vanuit dit kader laat begrijpen.

\section{Methoden van onderzoek}

In deze bijdrage wordt gebruikgemaakt van empirische gegevens die zijn verzameld in het kader van een recent onderzoek naar de inzet van bestuurlijke bevoegdheden en de betrokkenheid van de politie daarbij (Salet \& Sackers, 2019a). Hoewel het onderzoek een brede opzet kent, heeft een deel van het onderzoek zich met name geconcentreerd op de toepassing van drie bevoegdheden. Bij de keuze van deze drie bevoegdheden is gestreefd naar variatie ten aanzien van de aard van de bevoegdheden, de aard van de aan te pakken problematiek en de wijze waarop de politie betrokken is. Ten slotte moest het gaan om bevoegdheden die voldoende vaak worden ingezet, maar waarover nog niet veel (empirisch) onderzoek in Nederland beschikbaar is. Op basis van deze overwegingen is besloten het onderzoek te concentreren op de bevoegdheid tot een gebiedsverbod, de bevoegdheid tot woningsluiting en de toepassing van de Wet Bibob (zie uitgebreider Salet \& Sackers, 2019a).

In het onderzoek zijn twee wegen bewandeld. Allereerst hebben bij vijftien gemeenten persoonlijke interviews plaatsgevonden met vertegenwoordigers van deze gemeenten (onder wie medewerkers openbare orde en veiligheid, beleidsadviseurs en juridisch adviseurs) en vertegenwoordigers van de betreffende basisteams van politie (onder wie teamchefs, wijkagenten, operationeel experts en bestuurlijk experts). Het doel van deze interviews was om een beeld te krijgen van de wijze waarop Nederlandse gemeenten gebruikmaken van de burgemeestersbevoegdheden bij de aanpak van overlast en criminaliteit en wat de rol daarbij is van de politie. De interviews hadden een open karakter, waarbij gebruik is gemaakt van een vooraf opgestelde onderwerpenlijst. In totaal zijn 22 gemeentemedewerkers en 29 politiefunctionarissen geïnterviewd. Deze interviews vonden plaats verspreid over zes grote gemeenten (meer dan 100.000 inwoners), vier middelgrote gemeenten (50.000-100.000 inwoners) en vijf kleine gemeenten (tot 50.000 inwoners).

Daarnaast zijn casestudies uitgevoerd waarin is geprobeerd gedetailleerd zicht te krijgen op de wijze waarop de bevoegdheden worden gebruikt, welke rol de politie daarbij heeft, welke gevolgen dit heeft voor het politiewerk en welke factoren en omstandigheden daarbij een rol spelen. In totaal zijn tien concrete gevallen bestudeerd waarin gebruik is gemaakt van de geselecteerde burgemeestersbevoegdheden. Deze gevallen zijn onderzocht bij in totaal zeven verschillende gemeenten, waaronder zowel grote, middelgrote als kleine gemeenten. Voor de selectie van cases is gebruikgemaakt van informatie die is verkregen in de eerder afgenomen interviews. Daarbij is gestreefd naar zo veel mogelijk diversiteit in de te onderzoeken concrete gevallen. Per geval zijn de dossiers zoals die bij de gemeente 
voorhanden waren bestudeerd, aangevuld met relevante APV-bepalingen, beleidsdocumenten, veiligheidsplannen en beleidsregels. Vervolgens hebben aan de hand daarvan interviews plaatsgevonden met (de) betrokken medewerker(s) van de gemeenten en één of meer betrokken politiefunctionarissen. In deze fase zijn in totaal dertien gemeentemedewerkers en twaalf politiefunctionarissen geïnterviewd. Het veldwerk van deze studie heeft plaatsgevonden in de periode van oktober 2016 tot en met mei 2017. Onder andere in verband met de onwenselijkheid van herleidbaarheid tot concrete personen en/of zaken worden hier geen namen genoemd van gemeenten en politie-eenheden waar het onderzoek heeft plaatsgevonden. ${ }^{2}$

\section{Bestuurlijke bevoegdheden in de praktijk}

In de praktijk blijkt een deel van de burgemeestersbevoegdheden in de maatschappelijke veiligheidszorg (zoals de toepassing van bestuurlijke ophouding) niet of nauwelijks te worden toegepast (Salet \& Sackers, 2019a; vgl. De Jong e.a., 2017). Voor in elk geval de gebiedsverboden, woningsluitingen en Bibob-toetsen ligt dit anders. Deze worden in de praktijk regelmatig toegepast. Ook kleinere gemeenten maken gebruik van deze bevoegdheden. Voor een beter begrip van de verschillende bevoegdheden wordt in deze paragraaf op hoofdlijnen de toepassing van deze drie bevoegdheden in de praktijk beschreven. Dit is gebaseerd op de bevindingen die in het onderzoek naar de betrokkenheid van de politie bij de burgemeestersbevoegdheden zijn gedaan (Salet \& Sackers, 2019a). Hierbij wordt ingegaan op de problematiek waarvoor de bevoegdheden worden gebruikt en welke doelen die inzet heeft. Ook komen op hoofdlijnen de werkwijzen en de vraag of de toepassing onderdeel uitmaakt van een bredere aanpak aan de orde.

\subsection{Gebiedsverboden}

Gebiedsverboden worden ingezet bij problemen van overlast en criminaliteit veroorzaakt door bepaalde personen of groepen (zoals groepen jongeren en notoire overlastgevers), 'voetbalgerelateerde' overlast en 'gebiedgerelateerde' overlast (bijvoorbeeld in zogenoemde hotspots waar sprake kan zijn van overlast veroorzaakt door onder andere prostitutie, drugsgebruik en -dealen). Het voornaamste doel van het gebiedsverbod is het herstellen van de openbare orde. Door de overlastgever voor korte of langere duur uit het gebied waar de overlast plaatsvond te weren, wordt getracht hier de rust te laten terugkeren. In de praktijk wordt de bevoegdheid een gebiedsontzegging op te leggen doorgaans gebaseerd op bepalingen in de Algemene Plaatselijke Verordening of op artikel 172a Gemeentewet.

De duur van een gebiedsverbod varieert in de praktijk sterk (afgezien van mogelijke verlengingen, uiteenlopend van 8 uur tot 12 weken) en is onder meer afhankelijk van regelgeving en beleidsregels in de betreffende gemeente. In de meeste gemeenten is de bevoegdheid opgenomen in de Algemene Plaatselijke Verordening. De meeste gebiedsverboden worden op basis hiervan opgelegd. Veelal maakt 
de maatregel onderdeel uit van een bredere aanpak die gericht is op een bepaalde doelgroep (bijvoorbeeld jeugdgroepen of verslaafden) of een bepaald gebied (zoals een horecaconcentratiegebied). Hierbij kunnen naast politie en gemeente ook meerdere andere partijen, zoals hulpverleningsinstanties, betrokken zijn. Het gebiedsverbod wordt in deze verbanden zowel ingezet vanuit preventief als repressief oogpunt.

De politie speelt bij de inzet van gebiedsverboden een belangrijke rol. Politiemensen nemen in de regel het initiatief een gebiedsverbod op te leggen, nadat zij met de betrokken gemeentemedewerkers hebben afgestemd of een gebiedsverbod tot de mogelijkheden behoort. De politie verzamelt hiertoe zo veel mogelijk concrete informatie over de rol van de individuele overlastgever op basis waarvan de burgemeester beslist al dan niet een gebiedsverbod op te leggen. De politie reikt het verbod vervolgens uit en zij is ook verantwoordelijk voor de handhaving van het gebiedsverbod, waarbij wordt samengewerkt met medewerkers van de dienst Toezicht \& Handhaving. ${ }^{3}$

\subsection{Woningsluitingen}

Bij woningsluiting is in de meeste gevallen sprake van drugsgerelateerde overlast en criminaliteit. Woningsluiting vindt dan plaats op basis van artikel 13b Opiumwet $^{4}$ en beoogt de normale woonsituatie te herstellen en de illegale situatie te beëindigen. Herstel van de openbare orde is hierbij in de praktijk een belangrijk doel. Gemeenten proberen 'de loop uit het pand te halen'. Andere doelen, zoals het afgeven van een signaal door de gemeente dat zij krachtig optreedt tegen drugscriminaliteit en het verstoren van georganiseerde criminaliteit, zijn in de praktijk ook van belang. Of een woning direct wordt gesloten naar aanleiding van het aantreffen van drugs, hangt af van de aangetroffen hoeveelheid en of sprake is van hard- of softdrugs. In de meeste gemeenten wordt hier beleidsmatig onderscheid in gemaakt. Bij het aantreffen van een handelshoeveelheid harddrugs wordt de woning in de regel direct gesloten voor een periode van drie tot zes maanden, terwijl bij softdrugs doorgaans eerst een waarschuwing uitgaat.

Vaak kan een woningsluiting worden begrepen als een bestuurlijk vervolg op een strafrechtelijk onderzoek. De politie verstrekt aan de gemeente informatie die zij heeft verzameld naar aanleiding van het aantreffen van drugs in een woning. Met name bij de aanpak van hennep(teelt) zijn doorgaans meer partijen betrokken die met elkaar samenwerken op basis van een 'hennepconvenant'. In die gevallen gaat relevante informatie die de politie heeft verzameld niet alleen naar de gemeente maar ook naar andere partijen, zoals woningcorporaties, energiebedrijven en soms de Belastingdienst.

3 Voor de diensten van de gemeentelijke toezichthouders en handhavers worden verschillende termen gebruikt, zoals 'Stadtoezicht', 'Toezicht \& Handhaving' of 'Toezicht \& Handhaving Openbare ruimte' (Eikenaar \& Van Stokkom, 2014).

4 Er zijn ook andere juridische mogelijkheden voor sluiting van woningen door burgemeesters, maar in de praktijk wordt in de meeste gevallen gebruikgemaakt van art. 13b Opiumwet. 


\subsection{Bibob-toetsen}

Bestuursorganen kunnen bepaalde subsidies of vergunningen weigeren of intrekken, indien het gevaar bestaat dat daarmee strafbare feiten zullen worden gepleegd (of indien het vermoeden bestaat dat strafbare feiten zijn gepleegd). Zij kunnen zich daarbij laten adviseren door het Landelijk Bureau Bibob. Hiertoe is de Wet bevordering integriteitsbeoordelingen door het openbaar bestuur (Wet Bibob) in het leven geroepen.

In de praktijk proberen gemeenten met de Bibob-toets te voorkomen dat zij met verstrekte vergunningen georganiseerde of 'ondermijnende' criminaliteit faciliteren. De Bibob-toets wordt vaak ingezet voor vergunningen die worden verleend in specifieke branches, zoals seksinrichtingen, coffeeshops en horecabedrijven. Bij de beslissing over bijvoorbeeld een vergunningaanvraag ${ }^{5}$ maakt de gemeente gebruik van een eigen onderzoek (een lichte toets en/of een diepgaand onderzoek) of een uitgebreid onderzoek door het Landelijk Bureau Bibob. De politie is hierbij betrokken als informatieleverancier. Op basis van het onderzoek beslist de gemeente of een vergunning wordt verleend. Wanneer sprake is van een ernstig gevaar dat de te verlenen vergunning zal worden gebruikt om strafbare feiten te plegen of om voordeel verkregen uit gepleegde strafbare feiten te benutten, kan de gemeente de vergunning weigeren.

De Bibob-toets kan onderdeel uitmaken van een bredere (bestuurlijke) aanpak van overlast en criminaliteit in een bepaald gebied of in bepaalde branches. Deze bestuurlijke aanpak volgt vaak op of vindt gelijktijdig plaats aan een eventuele strafrechtelijke aanpak. Bij deze aanpak zijn doorgaans meerdere partijen betrokken, naast politie en gemeente bijvoorbeeld ook Openbaar Ministerie of Belastingdienst.

\section{Samenwerking bij gebiedsverboden, woningsluitingen en Bibob-toetsen}

In deze paragraaf wordt aan de hand van enkele concrete gevallen de samenwerking tussen politie en gemeente bij de inzet van bestuurlijke bevoegdheden beschreven. Hieruit zal blijken dat de wijzen van samenwerking in de praktijk sterk variëren, maar dat ook gemeenschappelijke factoren en patronen zijn te ontdekken.

\subsection{Samenwerking bij gebiedsverbod}

In een kleine Nederlandse gemeente wordt regelmatig overlast ervaren van een jeugdgroep. Deze jongeren zijn vaak luidruchtig en baldadig, plegen vernielingen en andere strafbare feiten. Bij de aanpak van deze overlast werken vertegenwoordigers van politie, gemeente, jongerenwerk, hulpverleningsinstanties en de dienst Toezicht \& Handhaving met elkaar samen aan een persoonsgerichte aanpak. Betrokken partijen verzamelen informatie over de

5 De Bibob-procedure kan worden gevolgd bij een vergunningaanvraag of reeds verstrekte vergunning, een subsidieaanvraag, vastgoedtransactie of aanbestedingsprocedure. Hier wordt telkens gesproken over een vergunningaanvraag. 
individuele overlastplegers om een beeld te krijgen van de persoonlijke levenssfeer. Gekeken wordt op welke wijze deze jongeren kunnen worden bewogen te stoppen met overlastgevend gedrag. Daarbij is afgesproken dat jongeren uit deze groep direct een 'waarschuwing gebiedsverbod' krijgen als zij een strafbaar feit plegen. Bij een tweede feit wordt een verbod uitgevaardigd.

Op enig moment treft de politie een aantal keren een 'nieuwe jongen' aan in de groep. Nog voordat over deze jongen tijdens overleg in het samenwerkingsverband kan worden gesproken, bedreigt de jongen iemand in het stadscentrum met een mes. De jongen krijgt van de politie direct een waarschuwing gebiedsverbod en een van de betrokken politiemedewerkers wordt aangewezen als verantwoordelijke voor de persoonsgerichte aanpak.

Een tijdje later is deze jongen betrokken bij een vernieling en wordt hem een gebiedsverbod opgelegd. Daarnaast vindt een gesprek plaats met zijn moeder en wordt een hulpverleningstraject opgestart. In overleg met Jeugdbescherming en Bureau Jeugdzorg doet de jongen mee aan een project. Na afloop daarvan keert de jongen niet meer terug in de betreffende gemeente en verdwijnt hij uit beeld bij het samenwerkingsverband.

Zoals in dit voorbeeld is in een deel van de gevallen waarin een gebiedsverbod wordt ingezet, sprake van een verregaand, breed samenwerkingsverband, waarbij ook andere partijen betrokken zijn. Kenmerkend hiervoor is dat betrokken partijen intensief met elkaar samenwerken. Zij overleggen regelmatig met elkaar. Alle partijen kunnen problemen signaleren, elkaar informeren en adviseren over de aanpak. Zij hanteren daarbij een gezamenlijke aanpak en voelen zich verantwoordelijk voor de geconstateerde problemen en de oplossing daarvan. In de regel worden in deze verbanden de gebiedsverboden ingezet in combinatie met of in aanvulling op andere maatregelen of interventies die onderdeel uitmaken van een bredere aanpak. De afstemming en integratie van de werkzaamheden is vergelijkbaar met het eerder onderscheiden 'coördinatiemodel'.

\subsection{Samenwerking bij woningsluiting}

De samenwerking tussen politie en gemeente (en andere partijen) bij woningsluiting gaat in een groot deel van de gevallen minder ver dan bij het gebiedsverbod. Kenmerkend aan de samenwerking is dat deze intensief is bij de aanpak van drugsgerelateerde overlast en criminaliteit. In concrete gevallen ontbreken echter (voorafgaande) afstemming en een gezamenlijk optreden. De samenwerking berust grotendeels op het uitwisselen van informatie tussen partijen, waarna iedere partij haar verantwoordelijkheid neemt voor haar deel van het probleem. Dat wil zeggen dat de politie zorgt voor het strafrechtelijk deel en de gemeente voor de woningsluiting. Eventueel zijn op regionaal niveau ook met andere partijen afspraken gemaakt over onder meer de wijze van informatie-uitwisseling en op welke wijze en in welke gevallen partijen optreden. Deze wijze van samenwerken sluit aan bij het 'coöperatiemodel'. Hoe dit in de praktijk verloopt, wordt duidelijk in het volgende concrete geval. 
Op een dag ontvangt een voor woningsluiting verantwoordelijke medewerker van een middelgrote gemeente een 'hennepinformatiebericht' van het districtelijk hennepteam van de politie. Uit het bericht blijkt dat in een huurwoning in de betreffende gemeente een hennepdrogerij met ongeveer 16 kilo natte hennep is aangetroffen. De medewerker neemt hierover contact op met de coördinator van het hennepteam omdat hij aanvullende vragen heeft over de hoeveelheid aangetroffen drugs.

Als de medewerker de zaak toevallig bespreekt met een collega, vertelt deze hem dat al langere tijd sprake is van 'onrust' in de buurt van de woning, omdat buurtbewoners het idee hebben dat 'er dingen gebeuren die ze niet vertrouwen'. Omdat het een woning van een woningcorporatie betreft, neemt de medewerker daarmee contact op. De vertegenwoordiger van de corporatie geeft aan het hennepinformatiebericht ook te hebben ontvangen en over te willen gaan tot ontbinding van de huurovereenkomst met de huurders.

De gemeentemedewerker wacht vervolgens de uitgebreidere bestuurlijke rapportage van de politie af. Op basis van die rapportage en naar aanleiding van het feit dat de woningcorporatie nog niet in staat is gebleken de huurovereenkomst te ontbinden, besluit de burgemeester de woning te sluiten voor een periode van drie maanden. Medewerkers van de dienst Toezicht \& Handhaving van de gemeente sluiten vervolgens de woning. De politie en het OM zorgen voor de strafrechtelijke afhandeling van de zaak.

\subsection{Samenwerking bij Bibob}

De rol van de politie bij het eigen onderzoek van de gemeente en bij de vraag of er een Bibob-toets moet worden verricht, is in de praktijk beperkt tot die van informatieleverancier. Politiemensen blijken niet of nauwelijks op de hoogte te zijn van de wijze waarop de Wet Bibob wordt toegepast. Zij zien deze bevoegdheid in de regel ook als instrument en verantwoordelijkheid van de gemeente, waarmee zij verder weinig bemoeienis hebben.

In de praktijk leidt dit ertoe dat de samenwerking rond Bibob meestal ad hoc plaatsvindt naar aanleiding van concrete gevallen. De samenwerking gaat niet veel verder dan het verstrekken van informatie. De mate van samenwerking kan wel worden geïntensiveerd, maar in de regel verloopt de samenwerking op afstandelijke wijze. De mate van integratie van de werkzaamheden is vergelijkbaar met het 'communicatiemodel'. Het volgende voorbeeld is hiervoor illustratief.

In een kleine gemeente komt een verzoek binnen tot overname van een exploitatievergunning voor een horecagelegenheid. De Bibob-formulieren voor deze aanvraag blijken incompleet te zijn en worden door de gemeente teruggestuurd. De betrokkenen besluiten hierna de poging tot overname te staken. Enige tijd later doen dezelfde personen een verzoek tot bijschrijving van een leidinggevende op de exploitatievergunning. Naar aanleiding hiervan vraagt de gemeente bij de politie de antecedenten op van de betrokkenen om te kunnen beoordelen of mogelijk sprake is van slecht levensgedrag. Het districtelijk informatieknooppunt van de politie verzorgt deze antecedenteninformatie. De informatie die de gemeente krijgt, is echter onduidelijk. Diverse 
strafbare feiten staan vermeld in de informatie, maar de rol van de betrokkenen daarbij is onduidelijk. Betrokkenen zouden zowel als slachtoffer, getuige, verdachte of anderszins betrokken kunnen zijn, maar dat volgt niet uit de informatie. Navraag bij het districtelijk informatieknooppunt en de wijkagent van het gebied waar de horecagelegenheid zich bevindt, leveren hierover ook geen duidelijkheid op. Ondanks deze onduidelijkheid doen de medewerkers van de gemeente een vooraankondiging dat de bijschrijving zal worden geweigerd. De aanvragers besluiten hierop de aanvraag in te trekken en gaan over tot de exploitatie van een horecazaak waarvoor geen vergunningen vereist zijn.

Uit het voorgaande blijkt dat de wijzen van samenwerking in de praktijk sterk variëren, maar dat ook gemeenschappelijke factoren en patronen naar voren komen die aansluiten bij drie van de vier in paragraaf 2 onderscheiden typen samenwerking. Hoewel alle drie typen samenwerking bij zowel de toepassing van gebiedsverboden, woningsluitingen als Bibob-toetsen zijn geconstateerd, komen bij iedere bevoegdheid overwegend één type of twee typen naar voren. Bij de gebiedsverboden zijn dit het coördinatiemodel en het coöperatiemodel, bij de woningsluiting het coöperatiemodel en bij Bibob het communicatiemodel.

\section{Relevante factoren voor de samenwerking}

Bij de wijze waarop de samenwerking in de praktijk verloopt, is een aantal factoren relevant. Deze sluiten aan bij uit eerder empirisch onderzoek naar interorganisationele samenwerking naar voren gekomen factoren en omstandigheden (zie par. 2).

Een van de belangrijkste elementen is vertrouwen tussen de betrokken partijen en de betrokken medewerkers. In veel gevallen gaat het bij de informatie-uitwisseling om (privacy)gevoelige informatie of informatie die een strafrechtelijk onderzoek kan frustreren. Wanneer sprake is van vertrouwen tussen betrokken medewerkers, zijn zij eerder bereid informatie op informele wijze met elkaar te bespreken (ook als die formeel niet mag worden gedeeld), zodat onderlinge afstemming van de werkzaamheden kan plaatsvinden. Frequent overleg (in persoon) tussen politie en gemeente, als ook informele, persoonlijke relaties tussen vertegenwoordigers van beide partijen kunnen het onderling vertrouwen bevorderen. Het gaat hierbij onder meer om 'korte lijntjes', 'elkaar kennen', 'elkaar weten te vinden' en 'elkaar kunnen bereiken' (vgl. o.a. Terpstra \& Kouwenhoven, 2004; Klijn, Edelenbos \& Steijn, 2010). Een groot verloop van bij de samenwerking betrokken medewerkers kan hierop een negatieve invloed hebben. Naar aanleiding van de veranderingen als gevolg van de komst van de Nationale Politie zegt een gemeentemedewerker hierover: 'Met al die bewegingen in die organisatie (de politie), met nieuwe poppetjes op nieuwe plekken, moet het vertrouwen zich wel weer settelen. Als dat steeds opnieuw blijft wisselen dan is het maar de vraag of je überhaupt wel zo'n relatie terugkrijgt die garant staat voor succes.' 
Daarnaast is van belang dat partijen elkaar informeren en op de hoogte brengen van welke stappen op welk moment worden gezet. De formele wijze van informatie-uitwisseling of het volgen van de formele procedures wordt daarom soms vermeden. Zo vertelt een medewerker van een gemeente: 'Als we alles via het centrale informatiepunt moeten laten lopen bij de politie, is het maar de vraag in hoeverre dat echt neerdaalt bij de politieman die ermee bezig is en wat daarvan terugkomt bij ons (...). Ik ben ook wel gebaat bij korte lijnen.' Bij de samenwerking is ook van belang dat betrokken medewerkers kennis hebben van elkaars bevoegdheden en de (on)mogelijkheden daarvan. Ten slotte wordt samenwerking bevorderd door een gemeenschappelijke definitie van de aan te pakken problemen en van de wijze waarop deze moeten worden aangepakt (vgl. Waardenburg e.a., 2016).

\section{Afstand tussen politie en gemeente}

Naast de hiervoor genoemde factoren en omstandigheden die een rol spelen bij de samenwerking tussen politie en gemeente, is de (ervaren) afstand tussen politie en gemeente van belang. In een deel van de gevallen blijkt deze afstand groot te zijn. Hoewel de afstand tussen de politie en gemeente bij de gebiedsverboden in zijn algemeenheid het kleinst is, wordt hier gesignaleerd dat de afstand groter wordt. Verschillende gemeenten constateren dat het aantal initiatieven van de politie om een gebiedsverbod in te zetten, sterk afneemt en dat politiemensen in samenwerkingsverbanden waarbij gebiedsverboden onderdeel uitmaken van de aanpak, regelmatig verstek laten gaan.

De afstand tussen politie en gemeente is bij de woningsluiting groter dan bij de gebiedsverboden. De woningsluiting wordt door politiemensen en medewerkers van gemeenten vooral gezien als een aanvulling op de strafrechtelijke aanpak van (met name) drugscriminaliteit. Betrokken partijen zijn verantwoordelijk voor hun eigen deel in de aanpak. De woningsluiting wordt primair gezien als de verantwoordelijkheid van de gemeente, terwijl de politie zich richt op de strafrechtelijke afhandeling van de zaak.

Bij het eigen onderzoek door de gemeente in het kader van de Bibob-toets en de vraag of er een Bibob-toets moet worden aangevraagd is de afstand het grootst. De betrokkenheid van de politie blijft hier beperkt tot het aanleveren van informatie. Daar komt bij dat die informatieverstrekking op grote afstand van de gemeente is georganiseerd, waardoor vaak lokale contextinformatie ontbreekt.

Deze grote afstand kan nadelige gevolgen hebben voor de wijze waarop de samenwerking bij de toepassing van bestuurlijke bevoegdheden verloopt. ${ }^{6}$ De geconstateerde afstand leidt soms tot weinig initiatief vanuit de politie en gebrekkige, contextloze informatie. Daarnaast is het bereiken van vertrouwen, 'korte lijntjes' en 'informele en persoonlijke relaties' nu eenmaal lastiger wanneer sprake is van meer afstand tussen betrokken partijen.

6 De afstand tussen gemeenten en politie op lokaal niveau in basisteams is doorgaans kleiner dan met politie op districts- of eenheidsniveau (uitgebreider Salet \& Sackers, 2019a). 
Voor het begrijpen van de afstand tussen politie en gemeente is van belang dat, zo blijkt uit dit onderzoek, een deel van de politiemensen op verschillende manieren probeert taken binnen het veiligheidsdomein op afstand te houden of af te stoten. In veel gevallen zijn politiemensen sterk gericht op handhaving door middel van het strafrecht en op hun 'kerntaken', ${ }^{7}$ waardoor zij zich niet altijd bewust zijn van de (on)mogelijkheden van burgemeestersbevoegdheden. Ook zien veel politiemensen de uitvoering van deze bevoegdheden niet als hun verantwoordelijkheid, maar bij uitstek als die van de gemeenten. Bovendien probeert een deel van de politiemensen met de toepassing van de bevoegdheden vooral strafrechtelijke handhaving te bevorderen of daarmee te compenseren voor het in hun ogen falende strafrecht (vgl. Kort e.a., 2014). Bijvoorbeeld met het sluiten van een woning kan een crimineel die strafrechtelijk niet kan worden aangepakt, toch 'hard worden geraakt'. Een deel van de politiemensen blijft problemen vooral strafrechtelijk benaderen, waarbij voor andere oplossingen wordt gekeken naar andere partijen, waaronder gemeenten. De komst van de burgemeestersbevoegdheden biedt hiertoe ook de mogelijkheid.

\section{Ambivalentie}

De wijze waarop de samenwerking tussen politie en gemeente verloopt en de rol die de politie speelt bij de toepassing van de burgemeestersbevoegdheden, laten zien dat de positie die de politie inneemt in het veiligheidsdomein tamelijk ambivalent is. Hier is geconstateerd dat een deel van de politiemensen zich bij voorkeur richt op, zoals eerder ook al bleek (zie Terpstra e.a., 2010; Van Dijk, Hoogewoning \& Punch, 2015), crime fighting en een harde repressieve aanpak. Andere taken worden daarom op afstand gehouden. Uit dit onderzoek blijkt echter dat politiemensen nog een stap verder gaan. Immers, als zij aan een harde, repressieve aanpak een bijdrage kunnen leveren in het kader van een bestuurlijke aanpak die soms een straffend karakter heeft (Salet \& Sackers, 2019a; Salet \& Sackers, 2019b), laten zij het regelmatig afweten. Zo schiet de kwaliteit van de informatie bijvoorbeeld in een deel van de gevallen tekort en leggen politiemensen de verantwoordelijkheid voor de uitvoering van de bestuurlijke bevoegdheden (in toenemende mate) bij gemeenten.

Deze terugtrekkende beweging van de politie gaat gepaard met de ontwikkeling dat gemeenten steeds meer taken in de aanpak van overlast en (georganiseerde) criminaliteit naar zich toe trekken. Met name de aanpak van georganiseerde criminaliteit is voor gemeenten een relatief nieuw domein. Gemeenten krijgen hier echter steeds meer bevoegdheden tot hun beschikking (bijvoorbeeld Wet van 12 december 2018 tot wijziging van de Opiumwet (verruiming sluitingsbevoegdheid), Stb. 2018, 481; en o.a. Sackers, 2010; Prins, 2016).

Uit dit onderzoek blijkt dat de wijze waarop gemeenten hiermee omgaan, varieert. Tegenover meer terughoudende gemeenten die slechts een bescheiden rol voor zichzelf zien in de bestuurlijke aanpak van (georganiseerde) criminaliteit, staan 
hard optredende gemeenten met een alternatieve aanpak voor de falende strafrechtelijke. Zij proberen hun eigen informatiepositie te verbeteren en zich onafhankelijk te maken van de politie die soms onvoldoende in staat is relevante informatie aan te leveren.

Toch blijkt de positie die gemeenten innemen in het veiligheidsdomein eveneens ambivalent te zijn. In dit onderzoek is geconstateerd dat gemeenten vinden dat de politie herhaaldelijk tekortschiet bij de bestuurlijke aanpak. De oplossing daarvoor wordt echter niet zonder meer gezocht in verbetering en versterking van de rol van de politie bij de bestuurlijke aanpak. Integendeel, een aantal burgemeesters pleitte nog niet zo lang geleden juist voor versterking van de middelen van de politie bij haar traditionele strafrechtelijke rol, namelijk uitbreiding van de recherchecapaciteit in de strijd tegen (georganiseerde) criminaliteit (o.a. Noordanus e.a., 2017). Bovendien probeert een deel van de gemeenten de eigen positie te versterken door zich onafhankelijk te maken van de politie (bijvoorbeeld door het versterken van de eigen informatiepositie) en door te vragen om nog meer bevoegdheden bij de aanpak van (georganiseerde) criminaliteit om de 'slagkracht te kunnen vergroten' en effectiever te kunnen optreden (Regioburgemeesters, 2017).

\section{Conclusie: verborgen strijd in het veiligheidsdomein}

Uit het voorgaande volgt dat een deel van de gemeenten bij de aanpak van overlast en (georganiseerde) criminaliteit 'in het gat probeert te springen' dat de politie laat vallen. Deze gemeenten proberen hun positie, middelen en bevoegdheden in het veiligheidsdomein te versterken. Deze 'winst' voor gemeenten in het veiligheidsdomein loopt parallel aan 'verlies' voor de politie. Dit verlies biedt de politie echter nog meer gelegenheid taken af te schuiven en zich nog sterker te richten op het domein van strafrechtelijke handhaving en het verdelen, verwerven en beschermen van de beschikbare hulpbronnen daarbij (vgl. Benson, 1975). Eerder was bij de aanpak van georganiseerde criminaliteit sprake van symbiotische interdependentie tussen politie en gemeente. Beide partijen beschikten over middelen en bevoegdheden die elkaar versterken. Deze interdependentie lijkt echter, door de wijze waarop de samenwerking in een deel van de gevallen thans verloopt, te verschuiven naar een competitieve interdependentie. Bij deze competitieve interdependentie concurreert de harde repressieve aanpak van gemeenten met de harde, repressieve aanpak door de politie. Daarbij betekent 'winst voor de een, verlies voor de ander' (Terpstra, 2001: 146). Richtte Benson (1975) zich met name op de notie dat interorganisationele samenwerking afhangt van de interdependentie tussen partijen, dit onderzoek laat zien dat de wijze van samenwerking op het niveau van de uitvoering ook de interdependentie kan doen veranderen.

Het voorgaande leidt tot de conclusie dat van consensus over de passende rol en het werkterrein van politie en gemeenten in het veiligheidsdomein geen sprake lijkt te zijn. Sterker, er lijkt hier eerder een verborgen strijd gaande te zijn. Deze verborgen strijd kan echter een effectieve aanpak van overlast en criminaliteit belemmeren. 


\section{Literatuur}

Bakker, I. (2009) Van goede wil en samenwerking: een onderzoek naar samenwerking in de aanpak van meerderjarige veelplegers. Den Haag: NICIS.

Benson, J.K. (1975) The interorganizational network as a political economy. Administrative Science Quarterly, 20(2), 229-249.

Berg, E. van den \& I. Maas (2013) Interorganisationele samenwerking in de publieke sector: een casestudie naar een netwerk van organisaties rond criminele jongeren. Mens \& Maatschappij, 88(2), 206-232.

Boutellier, H. (2005) Meer dan veilig: over bestuur, bescherming en burgerschap. Den Haag: Boom Juridische uitgevers.

Bryson, J.M., B.C. Crosby \& M.M. Stone (2006) The design and implementation of crosssector collaborations: propositions from the literature. Public Administration Review, $66,44-55$.

Cachet, A. \& R.S. Prins (2012) Ontwikkeling van het lokaal veiligheidsbeleid. In: E.R. Muller (red.), Veiligheid: veiligheid en veiligheidsbeleid in Nederland. Deventer: Kluwer, 477-495.

Dijk, A. van, F. Hoogewoning \& M. Punch (2015) What matters in policing? Change, values and leadership in turbulent times. Bristol: Policy Press.

Dupont, B. (2004) Security in the age of networks. Policing \& Society, 14(1), 76-91.

Eikenaar, T. \& B. van Stokkom (2014). Van stadswacht naar nieuwe gemeentepolitie? Gemeentelijk toezicht en handhaving in de openbare ruimte. Apeldoorn/Nijmegen: Politie \& Wetenschap/Radboud Universiteit Nijmegen.

Gestel, B. van \& M. Verhoeven (2011) Obstakels voor samenwerking: bevindingen uit de procesevaluatie van de programmatische aanpak mensenhandel. Justitiële verkenningen, 27(2), 23-39.

Johnston, L. \& C. Shearing (2003) Governing Security: explorations in policing and justice. London/New York: Routledge.

Jong, M.A.D.W. de (2013) Lokale openbare-ordehandhaving. In: F.C.M.A. Michiels \& E.R. Muller (red.), Handhaving. Deventer: Kluwer, 461-483.

Jong, M.A.D.W. de, W. van der Woude, W.S. Zorg, J.L.W. Broeksteeg, R. Nehmelman, I.U. Tappeiner \& H.R.B.M. Kummeling (2017) Orde in de openbare orde: een onderzoek naar verbetering van de toepasbaarheid en inzichtelijkheid van het openbare-orderecht. Deventer: Wolters Kluwer.

Klijn, E., J. Edelenbos \& B. Steijn (2010) Trust in governance networks: its impacts on outcomes. Administration \& Society, (42)2, 193-221.

Kort, J., M. Fedorova \& J. Terpstra (2014) Politiemensen over het strafrecht. Apeldoorn/ Nijmegen: Politie \& Wetenschap/Radboud Universiteit.

Lam J., R. van der Wal \& N. Kop (2018) Sluipend gif: een onderzoek naar ondermijnende criminaliteit. Den Haag: Boom criminologie.

Noordanus, P.G.A., J.A. Jorritsma, W.B.H.J. van de Donk, P.F.G. Depla, P.J.M.G. Blanksma-van den Heuvel \& A.G.J.M. Rombouts (2017) Opstaan tegen ondermijning. Brief geraadpleegd op www.nrc.nl/nieuws/2017/02/14/brandbrief-150-euro-miljoenvoor-deltaplan-tegen-drugscriminaliteit-a1545919 (oktober 2018).

O'Toole, L.J. (2012) Interorganizational relations and policy implementation. In: B.G. Peters \& J. Pierre (red.), The SAGE Handbook of Public Administration. London: Sage.

Page, S.B., M.M. Stone, J.M. Bryson \& B.C. Crosby (2015) Public value creation by crosssector collaborations: a framework and challenges of assessment. Public Administration, 93(3), 715-732. 
Popp, J.K., H.B. Milward, G. MacKean, A. Casebeer \& R. Lindstrom (2014) Inter-organizational networks: a review of the literature to inform practice. Washington: IBM Center for the business of government.

Prins, R. (2016). Safety first: how local processes of securitization have affected the position and role of Dutch mayors. Den Haag: Eleven International Publishing.

Prins, R. \& L. Cachet (2011) Integrale veiligheidszorg en de burgemeester. Tijdschrift voor Veiligheid, 10(1), 43-58.

Regioburgemeesters (2017) Proeve van wetgeving 'Voorkomen en Aanpakken ondermijning'. Te raadplegen via www.regioburgemeesters.nl.

Sackers, H.J.B. (2010) Herder, hoeder en handhaver. Nijmegen: Radboud Universiteit.

Salet, R. \& H.J.B. Sackers (2019a) Bestuurlijke bevoegdheden, politie en de lokale aanpak van onveiligheid. Apeldoorn/Nijmegen: Politie \& Wetenschap/Radboud Universiteit.

Salet, R. \& H.J.B. Sackers (2019b) Spanningen tussen de bestuurlijke en strafrechtelijke aanpak van criminaliteit. Nederlands Juristenblad , 2019/766, 14, 933-939.

Schuilenburg, M. (2012) Orde in veiligheid: een dynamisch perspectief. Den Haag: Boom Lemma uitgevers.

Schuilenburg, M. \& W. van der Wagen (2011) Samenwerking in de criminaliteitsbestrijding: kwalitatief onderzoek naar de integrale aanpak van illegale hennepteelt. Tijdschrift voor Veiligheid, 10(1), 10-25.

Steden, R. van (2011) Integraal lokaal veiligheidsbeleid: tussen retoriek en realiteit. Tijdschrift voor Veiligheid, 10(1), 3-9.

Steen, M. van der, J. Schram, N. Chin-A-Fat \& J. Scherpenisse (2016) Ondermijning ondermijnd. Hoe het rijk meer ruimte kan maken voor een (boven)lokale aanpak van georganiseerde ondermijnende criminaliteit, Den Haag: NSOB.

Terpstra, J. (2001) Netwerken en samenwerking bij de uitvoering van beleid. Beleidswetenschap, 2, 141-167.

Terpstra, J. (2008) Police, local government, and citizens as participants in local security networks. Police practice and research: An international journal, 9(3), 213-225.

Terpstra, J. (2010) Het veiligheidscomplex: ontwikkelingen, strategieën en verantwoordelijkheden in de veiligheidszorg. Den Haag: Boom juridische uitgevers.

Terpstra, J., L. Gunther Moor \& B. van Stokkom (2010) De kerntakendiscussie in Nederland: retoriek en realiteit. In: B. van Stokkom, J. Terpstra \& L. Gunther Moor (red.), De politie en haar opdracht: de kerntakendiscussie voorbij. Apeldoorn/Antwerpen: Maklu, 25-50.

Terpstra, J. \& R. Kouwenhoven (2004) Samenwerking en netwerken in de lokale veiligheidszorg. Apeldoorn/Enschede: Politie \& Wetenschap/IPIT Instituut voor Maatschappelijke Veiligheidsvraagstukken Universiteit Twente.

Tops, P.W., P. van Os \& E. van der Torre (2017) Sleuren en sturen in 2017: de ontwikkeling van de relatie tussen de politie en het lokaal bestuur. [z.p.]: Commissie Bestuur en Veiligheid van de Vereniging van Nederlandse Gemeenten.

Waardenburg, M., B. Keijser, M. Groenleer \& J. de Jong (2016) Probleemanalyse is het halve werk: samenwerking en innovatie in de strijd tegen ondermijnende criminaliteit. Bestuurswetenschappen, 70(2), 5-19.

Weber, E.P. \& A.M. Khademian (2008) Wicked problems, knowledge challenges, and collaborative capacity builders in network settings. Public administration review, 68(2), 334-349.

Zwaan, A.H. van der (1990) Netwerken: samenhang en samenwerking in de gezondheidszorg. In: J.A.M. Maarse \& I.M. Mur-Veeman (red.), Beleid en beheer in de gezondheidszorg: problemen, structuren, processen en effecten. Assen/Maastricht: Van Gorcum. 